\title{
Contemplating the Value of Liminality for Entrepreneurs
}

\author{
Faith Jeremiah', Adan E. Suazo², Russell Butson ${ }^{3}$
}

\begin{abstract}
The digital revolution is impacting enormously on the way we create and undertake business. To keep pace and navigate the complexities of this incessant evolving state requires entrepreneurial thinking capable of moving us from the old to the new. An often-overlooked aspect of this transition or change process is the space that lies between the old and the new, a betwixt and between state, fuelled by opportunity, but clouded in uncertainty and ambiguity. In this article, we stress the significance of this between space and discuss the importance of liminal thinking as pivotal in navigating the passage from old to new. We do this by drawing on the concepts of liminal space and liminal thinking, illustrating how these concepts can be deployed to reconstruct reality in such a way that stimulates the crucial cognitive recalibrations needed to cross the passage from old to new. To know that this 'betwixt and between' space exists, to recognise the qualities of this space and, most importantly, to manage it, is invaluable in entrepreneurs' dynamic, rapidly changing world.
\end{abstract}

\section{Keywords}

Liminal space, liminal thinking, change, entrepreneurs, entrepreneurial cognition and affect

\section{Introduction}

Stripped of any sense of self and dilapidated by each threshold faced, lost and strained by the whirlwind of change, regret, exploration and pained by the feeling of discomfort and uneasiness, he found himself in 'betwixt and between'.

From always knowing where he had been to where he was going, tightly bound by daily rituals to confronting a world of fog, unclear pathways, anxiety and fear, he was lost in the space between who he was and who he would be. He had invested everything, his energy, his love, he had sunk thousands of dollars, countless hours, time away from friends and family, gave up what he loved doing to chase this dream. He had abandoned his comfort zone to discard his daily rituals.

\footnotetext{
Higher Education Development Centre, University of Otago, New Zealand; http://orcid.org/0000-0001-8383-8893

2 Higher Education Development Centre, University of Otago, New Zealand; http://orcid.org/0000-0002-3087-402X

3 Higher Education Development Centre, University of Otago, New Zealand; http:/orcid.org/0000-0003-4039-4035
} 
This state was stressful, nothing was as it had been, he felt displaced in life, lost a sense of direction and his sense of self. The temptation burned strong to regress back to the familiar. ${ }^{4}$

Driven forward by opportunity and passion, yet withdrawing to the call of the familiar - the need to find control against a backdrop of chaos - these entrepreneurs are confronted by the thresholds of financial burden, invested resources, mental and physical energy, and challenged by feelings of loss and bewilderment. Yet, always aware that a process of change or transition is at the very crux of what they are seeking. Many an entrepreneur has stood at this crossroad and experienced the dark side of being 'betwixt and between'. Managed right, these situations can ground many entrepreneurs in the throes of perusal.

To know that this 'betwixt and between' space exists, to recognise the qualities of this space and, most importantly, to manage it, is invaluable in entrepreneurs' dynamic, rapidly changing world. However, discoursing about abstract, hypothetical states such as liminality is challenging and problematic. Notwithstanding, we feel that liminality can offer a tangible concept for materialising a typically abstract condition. For example, liminality offers a framework from which to conceptualise the disrupting potential of decisive acts of change: changes in thinking, in action and in aspirational shifts. It materialises the transitional condition that Prashanthama and Floyd (2019) describe as the threshold between two places, states-of-being, or eras; it is the interval between 'what was' and 'what's next.'

In this article, we aim to build a valuable and constructive case for the recognition and affordances that the concept of liminality can offer to the entrepreneurial endeavour. In some respects, this work represents a thought experiment on the relevance of liminal space and liminal thinking to entrepreneurship. We present various thoughts, ideas, and reflections and highlight the opportunities we believe these concepts could provide for business thinking theoretically and practically.

\section{The Concept of Liminality}

The godfather of liminality, anthropologist Arnold van Gennep (1909), first introduced this concept in his book Les Rites de Passage (Rites of Passage) where he explained that a rite of passage comprises three key stages: separating from the old state, transitioning between the old state and the new (liminal state) and assimilating the new state. The liminal state involves a temporary suspension in which the subject is neither one state nor the other - they are in a paradoxical condition where potentiality is at a maximum and actuality is at a minimum, facilitating a critical and creative attitude through liminal thinking (Söderlund \& Borg, 2018).

To illustrate, we have included an impression shared with us by an entrepreneurial colleague that depicts lifestyle change as a metaphoric voyage to sea:

As you excitedly share your idea, encouragement flows from friends and family, offers of advice and help are loosely promised, and loaded with blessings and affirmed self-belief, you are sent on your voyage. The sun shines, excitement burns, and tingling with flutters of nervous energy and anticipation, you set sail, blindly convinced you will reach the other

4 Experience shared by colleague of the authors. 
side. As unexpected challenges arise, and unanticipated routes must be crossed, the dawning realisation that you have journeyed alone dims your passion. The voices and waving hands have long faded and everything falls silent, except for the cold slap of the ocean against the hull; now everything is questioned and nothing seems as it should. You are confused as you find yourself 'lost at sea' and having to navigate your way in the darkness. The plan seems pointless and irrelevant now. You had thought the decision to 'change' was more straightforward, a process, or step-by-step direction. You hadn’t anticipated the burden of change. You turn the boat around towards the call of home. ${ }^{5}$

This metaphor illustrates the initial energy, excitement, confidence, self-belief and support that many people experience during transitional life-periods. Yet, when unforeseen mental and physical challenges arise, and the tension from states of disequilibrium grows, this very burden of change can shock and unsteady even the most confident of individuals. This tension is derived from experiencing the uncomfortableness of the unknown, feeling displaced, uncertain and not knowing how to navigate out. The fear of the unknown is confronting. Everything that is recognised and familiar no longer exists in this space. People scan their memory in search of a previously trodden path, yet are cognisant that previous ways of thinking cannot be drawn on while they are in this space.

\section{The Relevance of 'Liminality' in Times of Rapid Change}

Given the turmoil of change as we transition into the digital era, it is not surprising to see the concept of liminality, which was ignored by social sciences for over 50 years (see Thomassen, 2014 for a detailed analysis), making a comeback (Ibarra \& Obodaru, 2016). Many disciplines are using this concept, including... sociology (Berkowitz, 2011; Lahad, 2012; Smith, 2013), religion (Junker, 2013; Kaltner, 1997; Ludlow, 2012), political science (Thomassen, 2009), and marketing (Al-Abdin et al., 2016; Cody \& Lawlor, 2011; Izak, 2015; Thomsen \& Sorensen, 2006). Despite the transient state of business generally and entrepreneurial studies in particular, interest in the concept of liminality has been somewhat limited (Garcia-Lorenzo et al., 2018; Söderlund \& Borg, 2018).

In organisation and management research, the concept of liminality has typically been treated as a condition that is imposed by a profession or a particular role, where the liminal state is often portrayed as having negative outcomes. For example, temporary staff (Garsten, 1999), consultants (Czarniawska \& Mazza, 2003), workers affected by role changes (Ibarra \& Obodaru, 2016), or identity shifts in organisational settings (Ybema, Beech, \& Ellis, 2011; Zabusky \& Barley, 1997). However, in the few entrepreneurial studies on liminality (Söderlund \& Borg, 2018), this concept has been positioned as a positive transformation state (Anderson, 2005), a space that allows entrepreneurs to discover their true sense of self (Brooker \& Joppe, 2013), and that stimulates them to foster new possibilities and align current resources and strategic action (Henfridsson \& Yoo, 2014). Yet, Söderlund and Borg (2018) argue that the scant research on liminality, as it applies to business studies, exposes integral problems and tensions in entrepreneurship when transitioning from one condition and identity to another, including the

5 Experience shared by colleague of the authors. 
significant challenges and consequences of developing and living with multiple identities and competing system demands.

The absence of studies examining the concept of liminality and its application in the business sector means little is known about what transpires during the threshold from prospective entrepreneur to business person, or even the sub-stages of entrepreneurship, where the entrepreneur is in-between the current state and some future state of business expansion. This lack of research is surprising given that entrepreneurs typify the transformative condition that locates them in the "half-way house of becoming" (Anderson, 2005, p. 598), as they participate in a process of creating possible futures. We would argue that this transformative landscape offers the possibility to investigate such 'in-between' states. This would afford us an understanding of how these contexts enable adaptive and maladaptive practices and impact on the junctions of change, and the associated internal conflict and motivations.

\section{Taming Liminal Space and Mastering Liminal Thinking}

Navigating the complexity of change requires a willingness to reconstitute the status quo and the order it brings with it. We refer to this ability to reconstitute the status quo as liminal thinking: a process that traverses existing mental thresholds and that facilitates the shaping, reframing and adoption of new understandings and beliefs with minimal prejudice. In this way, liminal thinking represents the purposeful act of disrupting existing mental maps.

Given this, we could safely assume liminal thinkers willingly accept the resulting disequilibrium of thought and action inherent in changing conditions as their assumptions and presumptions are found wanting. In this regard, the entrepreneurial world provides some relevant examples that help elucidate liminal thinkers' mindsets and attitudes toward change. For example, entrepreneurs such as Jenna Lyons, former president of J. Crew, understand and embrace the liminal space by weaving risk-taking into the fabric of their companies, leading to exciting and profitable transformations (Sacks, 2014). Similarly, industries that have successfully employed liminal thinking have identified the opportunities and benefits of uncertainty. Hingston (2014), for example, points to the funeral industry as a case where businesses that captured the shifting wants and needs of the public, and those that have harnessed the power of technological change, have succeeded in remaining competitive. Voigt et al. (2017) similarly extol the risk-taking merits of Amazon executives as they steered the company from its original book retailer space to its current e-commerce/multimedia configuration. In short, liminal thinkers who espouse an overt embrace for change, such as entrepreneurs, are those most likely to succeed in delving into the depths of liminality, voluntary or otherwise, to be born anew, and to influence wider individual and institutional-level change.

Liminal thinkers follow a risk-taking pathway (Pines et al., 2004): they are independent thinkers re-examining the status quo and finding new solutions or opportunities through an inquisitive mindset. Such liminal minds embrace a belief that change at its very core is disruptive, but that its uncomfortable and unfamiliar taste does not necessarily lead to adverse outcomes: positive disruption can lead individuals to reap the benefits of creativity and dynamism (Forrester, 2016) by becoming willing parties to what Schumpeter calls the process of creative destruction, where revolutionised mental models and structures incessantly destroy and replace the old (Kalfa, 2014). 
The liminal space experience can be enriched and maximised by cognitively reframing the 'unknown' as a creative opportunity. The excitement and novelty during times of innovation, creativity and discovery can deepen engagement and accelerate learning (Henseley, 2020; Hlioui et al., 2020). Yet, while humans' makeup is fundamentally driven towards evolving and finding new, more efficient ways of living and working; at times, we fear or are burdened by change and, instead, benefit from the security of structures and institutionalism.

Here, consistency is preferred, whereby the very essence of knowing what to expect in a given situation can give us a degree of stability. Consider, for example, large global franchises (e.g., McDonalds) and supermarket chains (e.g., Walmart) who maintain uniformity in their products and services to offer the same standardised consumptive experiences. Systems and structures form security, a clear path and a series of mental models, which together facilitate a certain comfort of being "creatures of habit” (Mendelsohn, 2019; Wood \& Rünger, 2016).

Many high-risk business endeavours can be subconsciously perceived as a threat, which in turn can inhibit change initiatives in our lives or in the business world. For example, every time an entrepreneur starts a new business or initiates a change, they go through cognitive reasoning, risk evaluation and emotional stages to either inhibit or promote change. However, if the prospective entrepreneur retreats, they may find they invested the same level of energy as if they had carried on, for going back means accepting the pre-liminal state and the financial, social and psychological costs of failure normally attached to it (Ucbasaran et al., 2013); by persisting through the liminal space results in a changed person with a shift in previously held mental maps (Figure 1).

Image 1. Liminal Space and Directional Choices

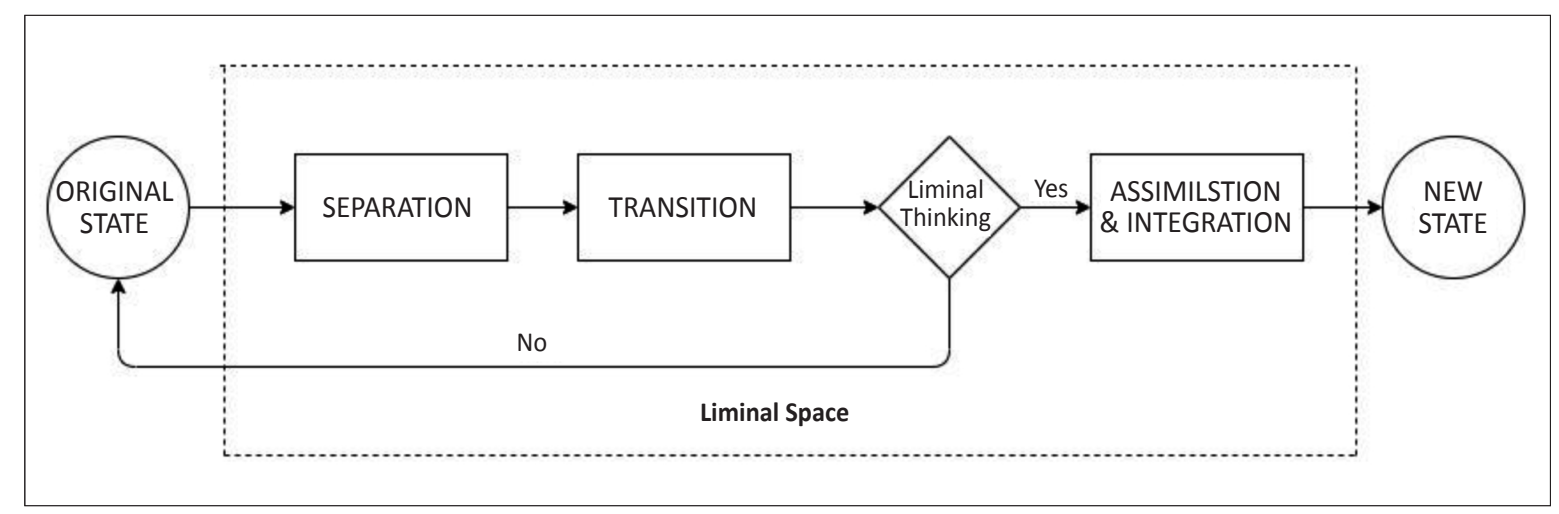

It is important to note that while individuals experience liminality differently, the probability of a successful outcome will be dependent on a person's embrace of liminal thinking, especially their ability to see the opportunity structure of an idea as a function of a person's progression from one state to another. It is a state of thinking that draws heavily on creativity and originality (figure 2).

A non-liminal thinker would assume, based on their conceptions of risk and opportunity, that more predictable environments are most likely to maximise dividends. Therefore, such a thinker bases their decision-making on those very principles. As shown in Figure 2, we propose an alternative route: liminal thinking entails a personal ownership of change, regardless of the unpleasant and the unknown. The inherent opportunities outweigh the negative, justifying the move from one state to another. In this regard, navigating the liminal space entails a strong 
conviction over one's guiding objectives and a respectful regard and preparation for uncertainty. The opportunity structure under liminal thinking, represented by the blue line in Figure 2, must always be perceived as directly proportional to one's navigation from one original state to another, and not as a function of predictability and risk. Anything short of this is likely to result in regressions to a previous state.

Image 2. Predictability and the Liminal Space

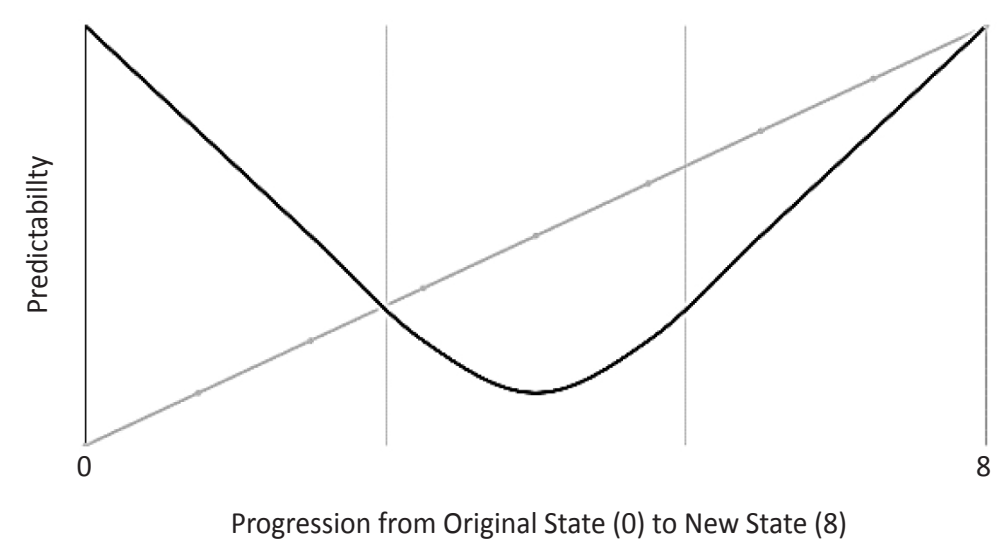

Liminal thinking first manifests when one is aware that the liminal space exists. Awareness is then met with a physical and mental preparedness for what will transpire in this space, followed lastly by a will to persevere through it. Liminal thinking permits a subject's navigation through the often-gruelling state of disequilibrium that is the liminal space, through a constant reminder of the difficult, yet achievable path ahead. Part of liminal thinking involves a consistent check of one's attachments to old mental models and frameworks and the extent to which they prevent us from progressing from an original state to another. This thinking can increase our tenacity to persist through the liminal space.

Entrepreneurial research has recognised the value in persevering through times of difficulty and challenge (Greg, et al., 2019; Holland \& Shepherd, 2013; Holland \& Garrett, 2015). Yet, remaining resilience while feeling fragile, vulnerable and exposed places entrepreneurs within an onerous space. The caveat is that liminal thinking is likely to facilitate the development of antifragility, increasing empowerment and resilience as a result of overcoming disorder, chaos or stress (Taleb, 2012). This antifragility builds mental and emotional fortitude through wilful exposure to liminality-driven trauma. To illustrate antifragility, we could consider human evolution, immunity from illness or strength training: processes where the recipient of trauma is advantaged by its exposure to it... while wind extinguishes a candle, a fire is energised. Therefore, what liminal thinking facilitates is the development of antifragility within a liminal environment, helping an individual navigate from one state to another.

The application of liminal thinking in the business world has never been timelier. Being aware of, prepared for, and persistent in the face of the complexity, novelty and uncertainty of the liminal space could determine the extent to which an enterprise is likely to survive and grow. For example, Warbroek et al. (2019) find evidence that suggests that low carbon energy initiatives, crucial for the transition toward a fossil-fuel-free energy regime, are more likely to succeed when entrepreneurial risks are mitigated through support from public institutions, and through 
effective engagement with their communities. Similarly, Garcia Martinez et al. (2019) argue that business failure during times of financial instability can be effectively prevented by enhancing research and developing human capital, and through cross-enterprise cooperation. Both of these are potential mitigators of risk and uncertainty. The shock resulting from the uncertainty of the liminal space is best approached by espousing a mindset that is open to continuous exposure to new and potentially uncomfortable situations, and to being proactive in considering creative and collaborative avenues to help one navigate through the unknown.

\section{The Challenge in Researching Liminality}

Investigating the affordances of liminality is essential if we wish to comprehend the nature of transitional change processes in the business sector and elsewhere, and to explain what brings someone to a state of transformation. From this position, we argue that liminality is present long before the onset of change; researching liminality is therefore about examining the spaces before, during and after change occurs.

The challenge here lies in how we identify the catalysts of change and how we then relate theory and practice to support those engaging in liminal experiences. How and when do we determine entrance and exist states? Liminality as a concept is difficult to express in applied and functional terms. The case for realising this liminal process lies in identifying the cogent elements and characteristics of liminal space, including the role of thought processes involved, and progression and regression (movement) within liminality.

Framing the concept of liminality in a research inquiry has traditionally followed a threephase approach: separation phase, liminal phase and the incorporation phase (Turner, 1969). The separation phase involves detachment from routine norms, questioning subconscious beliefs, rejecting perceived realities and identity undoing (Nicolson and Carroll, 2013); it is a process of separation leading to unease. This is followed by the 'liminal phase,' where transitions flavoured by vagueness and uncertainty become dominant for the subject (whether individual or collective) experiencing change (Söderlund \& Borg, 2018). Finally, the 'incorporation phase' differentiates integration leading to a new and relatively stable state in which obligations and norms differ from those of the initial state (Turner, 1969).

While useful in identifying a pathway through which individuals embrace and adopt change, such neatly-delineated phases employed by theorists like Turner does not fully account for the chaos and unpredictability of change, and how these elements influence individuals' passage through liminal space. Transformation conjures a state of disorientation while abandoning something in pursuit of the new, causing internal conflict between discomfort/anxiety, and excitement/exploration. Knowing this, we suggest that states of transition cannot be expressed by fixed phases. Instead, we remind readers that these 'betwixt and between' states are intrinsically attached to ambiguity, which then influences one's cognitive, affective and social dimensions.

In identifying, roughly, the characteristics of a changing condition, new research that employs liminality as the main analytical instrument needs to examine the factors that influence individuals' decision to enter a liminal environment. Once the liminal space has been entered, it is also important to identify the different variables that dictate the extent to which an individual is permitted to sustain themselves during their passage through this space. These variables can take the shape and form of numerous personal, environmental, psychological, 
physiological and structural traits, which together may determine an individual's likelihood to thrive during a changing condition. Additionally, future studies should investigate variations between voluntary and involuntary entries into the liminal space. Whereas individuals are likely to enter a liminal setting by way of their own decision-making, such as those starting a new enterprise, others may be subject to situations where the liminal space is imposed upon them, such as an employee becoming redundant during a company's restructuring process. Are the variables that interact with a liminal subject the same, whether the liminal space is entered freely or not? What tools can be employed by liminal subjects in the face of voluntary or involuntary entries into the liminal space?

Research that employs liminality may use numerous data collection strategies to adequately measure and examine the different aspects of a liminal environment, and of those navigating through it. For example, researchers can employ traditional tools such as journal-keeping, where perceptions regarding daily decision-making processes can provide a first-person account of an individual's views over its passage through liminal space. Alternatively, advances in wearable technologies now afford us the ability to generate accurate accounts concerning psychological, physiological and environmental experiences of the person as they transition through various liminal states. By employing sensor-based instruments, researchers can gain important insights into the psychophysiological effects of entering a liminal environment, such as measures of routine, stress states, measures of mood, sleeping patterns and other cognitive impacts. Lastly, we suggest there are opportunities for research to taxonomise both the liminal space and its subjects in relation to the requirements and character of their respective industry. Developing a specific understanding of how the liminal space is felt and lived across sectors will allow researchers to identify industry-specific challenges, particularly in regard to adaptive and maladaptive practices. In turn, this will shed important light on potential strategies that could be deployed in the face of liminality-driven adversity.

\section{Conclusion}

The metaphorical expressions throughout this article capture the cognitive journey through some of the most confronting and challenging times of transition, where the burden to change and the fear of the unknown confront the liminal subject, even if they are driven by opportunity. We have implied that liminal space is entered through a deliberate embrace of liminality, which can interrupt subconscious daily rituals and cognitive processes, as established practices are brought into question. We view this disruption as a process of positive self-mutation (disrupting self) that incessantly revolutionises mental models from within by continuously destroying the old models and creating new ones. To successfully navigate through the disorientation felt in the liminal space, we position liminal thinking as key to enabling individuals to persevere. It is important to note that while our focus in this article lies on bringing value to entrepreneurial studies, we acknowledge the very same liminal experiences can be experienced by any person/s confronting traditional mental models when undertaking change, either deliberate or involuntary.

As part of our liminal discussion, we have embarked on a personal quest to inform, and indeed caution, entrepreneurs of change as they enter the liminal space. Here we would remind the supporters and aspirants of entrepreneurial endeavours of the confronting changes to their self-identity, routines and rituals, thought processes and the seemingly mundane of daily lives, 
which will shift in the face of deliberate or unforeseen change, such as undertaking a new venture. The unknown, such a core trait of liminal space, does not necessarily need to inspire fear, doubt and regression to an original state; it can influence creative thinking, renew the mind and spirit, and can deconstruct reality in such a way that permits crucial recalibrations through dynamic entrepreneurship. Those entrepreneurs who have progressed through the liminal space will become antifragile and stronger, more confident, and have an advanced sense of self.

Faced with continuous change due to the dramatic rise in technological advances and new ways of working, maintaining a competitive edge means entrepreneurs need to incessantly adapt, and it will be those entrepreneurs who do so whose business will mirror their evolving self as they appreciate the relevance of the liminal space and liminal thinking. We hope that our discussion is seen as an open invitation to continue this liminal discourse in entrepreneurial research.

\section{References}

Anderson, A. R. (2005). Enacted metaphor: The theatricality of the entrepreneurial process. International Small Business Journal, 13(2), 587-603.

Anderson, A. R., \& Warren, L. (2011). The entrepreneur as hero and jester: Enacting the entrepreneurial discourse. International Small Business Journal, 29(4), 589-609.

Brinckmann, J., Villanueva, J., Grichnik, D., \& Singh, L. (2019). Sources of strategic flexibility in new ventures: An analysis of the role of resource leveraging practices. Strategic Entrepreneurship Journal, 13(2), 154-178.

Brooker, E., \& Joppe, M. (2013). Developing a tourism innovation typology: Leveraging liminal insights". Journal of Travel Research, 53(1), 500-508.

Burke, C., \& Morley, M. (2016). On temporary organizations: A review, synthesis, and research agenda. Human Relations, 69(2), 1235-1258.

Cody, K., \& Lawlor, K. (2011). On the borderline: Exploring liminal consumption and the negotiation of threshold selves. Marketing Theory, 11(1), 207-228

Czarniawska, B., \& Mazza, C. (2003). Consulting as a liminal space. Human Relations, 56(4), 267-290.

Cooper, A. C., Gimeno-Gascon, F. J., \& Woo, C. Y. (1994). Initial human and financial capital as predictors of new venture performance. Journal of Business Venturing, 9(5), 371-395.

Dean, D., \& Nicholson, J. D. (2016). The transition of the self through the Arab spring in Egypt and Libya. Journal of Business Research, 69(2), 45-56.

Forrester, J. (2016). Embrace change for greater productivity: The commercial property sector needs to embrace positive disruption to stay ahead of the curve (Workplace Careers/Management/ Moves). Property Week, 83(18), 61.

Garcia-Lorenzo, L., Donnelly, P., Sell-Trujillo, L., \& Imas, J. M. (2018). Liminal entrepreneuring: The creative practices of nascent necessity entrepreneurs. Organization Studies, 39(2-3), 373-395.

Garcia Martinez, M., Zouaghi, F., Garcia Marco, T., \& Robinson, C. (2019). What drives business failure? Exploring the role of internal and external knowledge capabilities during the global financial crisis. Journal of Business Research, 98, 441-449.

Murphy, G., Tocher, N., \& Burch, T. (2019). Small business owner persistence: Do personal characteristics matter? Journal of Small Business Strategy, 29(1), 99-114.

Henfridsson, O., \& Yoo, Y. J. (2014). The liminality of trajectory shifts in institutional entrepreneurship. Organization Science, 25(2), 932-950.

Hensley, N. (2020). Educating for sustainable development: Cultivating creativity through mindfulness. Journal of Cleaner Production, 243, 118542. 
Hingston, S. (2014). The Death of the Funeral Business. In D. Starkman, M. M. Hamilton, \& R. Chittum (Eds.), The Best Business Writing 2014 (pp. 427-439): Columbia University Press.

Hlioui, F., Aloui, N., \& Gargouri, F. (2018). Understanding Learner Engagement in a Virtual Learning Environment. Paper presented at the Joint Conferences on 18th International Conference on Intelligent Systems Design and Applications, ISDA 2018 and 10th World Congress on Nature and Biologically Inspired Computing, Vellore.

Holland, D. V., \& Garrett, R. P. (2015). Entrepreneur start-up versus persistence decisions: A critical evaluation of expectancy and value. International Small Business Journal, 33(2), 194-215.

Holland, D. V., \& Shepherd, D. A. (2013). Deciding to persist: Adversity, values, and entrepreneur's decision policies. Entrepreneurship Theory and Practice, 37(2), 331-358.

Ibarra, H., \& Obodaru, O. (2016). Betwixt and between identities: Liminal experience in contemporary careers. Research in Organizational Behaviour, 36(8), 47-64.

Izak, M. (2015). Situational liminality: Mis-managed consumer experience in liquid modernity. Scandinavian Journal of Management, 31(7), 178-191.

Junker, D. B. A. (2013). Zone of proximal development, liminality, and communitas: Implications for religious education. Religious Education, 108(3), 164-179.

Kalfa, K. (2014). On Creatively Destructing. Rethinking Marxism, 26(4), 581-591.

Kaltner, J. (1997). Law and liminality in the Bible. Catholic Biblical Quarterly, 59(1), 752-753.

Lafontaine, F., Zapletal, M., \& Zhang, X. (2019). Brighter prospects? Assessing the franchise advantage using census data. Journal of Economics \& Management Strategy, 28(2), 175-197.

Lahad, K. (2012). Singlehood, waiting, and the sociology of time. Sociological Forum, 27(3), 163-186.

Ludlow, M. (2012). Demons, evil, and liminality in Cappadocian theology. Journal of Early Christian Studies, 20(2), 179-211.

Mendelsohn, A. I. (2019). Creatures of habit: The neuroscience of habit and purposeful behaviour. Biological Psychiatry, 85(11), e49-e51.

Nicolson, H., \& Carroll, B. (2013). Identity undoing and power relations in leadership development. Human Relations, 66(4), 1225-1248.

Pines, A. M., Dvir, D., Sadeh, A., \& Arden (2012). Dispositional antecedents, job correlates and performance outcomes of entrepreneurs' risk taking. International Journal of Entrepreneurship, 16(2), 95-112.

Prashantham S., \& Floyd S. W. (2019). Navigating liminality in new venture internationalization. Journal of Business Venturing, 3(3), 22-29.

Sacks, D. (2014). How Jenna Lyons transformed J. Crew into a Cult Brand. In D. Starkman, M. M. Hamilton, \& R. Chittum (Eds.), The Best Business Writing 2014 (pp. 385-399): Columbia University Press.

Smith, L. R. (2013). Female refugee networks: Rebuilding post-conflict identity. International Journal of Intercultural Relations, 37(4), 11-27.

Söderlund, J., \& Borg, E. (2018). Liminality in management and organization studies: Process, position and place: Liminality in management and organization studies. International Journal of Management Reviews, 20(4), 880-902.

Taleb, N. N. (2012). Antifragile: Things that Gain from Disorder. London, United Kingdom: Penguin Books Ltd.

Thomassen, B. (2009). The uses and meanings of liminality. International Political Anthropology, 2(6), 5-27.

Thomassen, B. (2014). Liminality and the Modern: Living Through the In-between. London: Routledge

Thomsen, T. U., and Sorensen, E. B. (2006). The first fourwheeled status symbol: Pram consumption as a vehicle for the construction of motherhood identity. Journal of Marketing Management, 22(8), 907-927.

Turner, V. (1969). The Ritual Process: Structure and Anti Structure. Chicago, IL: Aldine 
Ucbasaran, D., Shepherd, D., Lockett, A., \& Lyon, S. (2003). Life after business failure: The process and consequences of business failure for entrepreneurs. Journal of Management, 39(1), 163-202.

Van Gennep, A. (1909). Les Rites de Passage. Paris: Emile Nourry.

Van Praag, C. M. (2003). Business survival and success of young small business owners, Small Business Economics. 21(1), 1-17.

Voigt, K. I., Buliga, O., \& Michi, K. (2017). Business model pioneers: how innovators successfully implement new business models. Switzerland: Springer International Publishing.

Warbroek, B., Hoppe, T., Bressers, H., \& Coenen, F. (2019). Testing the social, organizational, and governance factors for success in local low carbon energy initiatives. Energy Research and Social Science, 58.

Wood, W., \& Rünger, D. (2016). Psychology of Habit. Annual Review of Psychology, 67(1), 289-314.

Ybema, S., Beech, N., \& Ellis, N. (2011). Transitional and perpetual liminality: An identity practice perspective. Anthropology Southern Africa, 34(1-2), 21-29.

Zabusky, S. E., \& Barley, S. R. (1997). "You can't be a stone if you're cement”: Reevaluating the emic identities of scientists in organizations. Research in Organizational Behavior, 19, 361-404. 